Vol 4 No 1 (2021) 111-125 P-ISSN 2620-295 E-ISSN 2747-0490

DOI: 1047467/elmal.v4i2.539

\title{
Pengaruh Islamic Branding, Celebrity Endorser, dan Pengetahuan Produk terhadap Keputusan Pembelian Konsumen Kosmetik Wardah
}

\author{
Nurul Luthfiani Pamungkas ${ }^{1}$, Ibdalsyah ${ }^{2}$, Retno Triwoelandari ${ }^{3}$ \\ 1.2.3FAI Universitas Ibn Khaldun Bogor \\ nurulltfn21@gmail.com¹, buyaibdalsyah@gmail.com², \\ retnotriwoelandari@gmail.com³
}

\begin{abstract}
The increasingly fierce business competition causes producers to have a marketing strategy that can attract consumer buying interest. Cosmetic products are considered to have great potential, especially for halal cosmetic products. The concept of Islamic branding and the concept of marketing using celebrity endorsers is very attractive to consumers' buying interest. There is still a lack of consumer understanding about halal standards for a product, causing producers to have to provide clear information for the products to be sold. This study aims to determine the effect of Islamic branding, celebrity endorser and product knowledge on consumer purchasing decisions for Wardah cosmetics. The research method used is a quantitative method. The population in this study were students of the Faculty of Islamic Religion, Ibn Khaldun University, Bogor with a total sample of 88 respondents. The data analysis method used is SEM-PLS. The results showed that; 1) The Islamic branding variable has a positive but not significant effect on purchasing decisions, 2) The celebrity endorser variable and product knowledge have a positive and significant effect on purchasing decisions. Even though Wardah products already have a halal certificate and use muslimah advertising stars, they are still not enough to influence purchasing decisions. Wardah can improve marketing by adding more Islamic themes.
\end{abstract}

Keyword: Islamic Branding, Celebrity Endorser, Product Knowledge

\section{ABSTRAK}

Pertumbuhan persaingan bisnis yang semakin ketat menyebabkan produsen harus memiliki strategi pemasaran yang dapat menarik minat beli konsumen. Produk kosmetik dianggap memiliki potensi yang besar terutama untuk produk kosmetik halal. Konsep islamic branding dan konsep pemesaran menggunakan celebtiry endorser ini sangat menarik minat beli konsumen. Masih kurangnya pemahaman konsumen tentang standar halal untuk suatu produk menyebabkan produsen harus memberikan informasi yang jelas untuk produk yang akan dijual. Penelitian ini bertujuan untuk mengetahui pengaruh islamic branding, celebrity endorser dan pengetahuan produk terhadap keputusan pembelian konsumen kosmetik Wardah. Metode penelitian yang digunakan adalah metode kuantitatif. Populasi dalam penelitian ini adalah mahasiswi Fakultas Agama Islam Universitas Ibn Khaldun Bogor dengan jumlah sampel 88 responden. Metode analisis data yang digunakan adalah SEM-PLS. Hasil penelitian menunjukan bahwa; 1) Variabel islamic branding berpengaruh positif tapi tidak signifikan terhadap keputusan pembelian, 2) Variabel celebrity endorser dan pengetahuan produk berpengaruh positif dan signifikan terhadap keputusan pembelian. Walaupun produk Wardah sudah memiliki sertifikasi halal dan menggunakan bintang iklan muslimah tetapi masih kurang cukup untuk mempengaruhi 


\section{Vol 4 No 1 (2021) 111-125 P-ISSN 2620-295 E-ISSN 2747-0490 DOI: 1047467/elmal.v4i2.539}

keputusan pembelian. Wardah bisa meningkatkan pemasaran dengan lebih banyak menambahkan tema-tema yang lebih islami.

Kata kunci: Celebrity Endorser, Islamic Branding, Pengetahuan Produk

\section{PENDAHULUAN}

Pertumbuhan persaingan bisnis yang semakin ketat menyebabkan produsen harus memiliki strategi pemasaran yang dapat menarik minat beli konsumen. Produsen diharapkan dapat memenuhi kebutuhan konsumen dengan menyediakan berbagai jenis pilihan dari produk sesuai dengan kebutuhan dan keinginan konsumen. Persaingan bisnis dalam perkembangan di era globalisasi saat ini, secara tidak langsung menyebabkan pengaruh yang sangat besar terhadap bidang perkekonomian. Semakin berjalannya waktu, semakin banyak produk baru di pasaran sehingga perusahaan harus membuat ciri khas tersendiri dari produk mereka untuk dapat bersaing. Perusahaan harus fokus terhadap persaingan merek, agar dapat bersaing secara kompetitif. Dengan adanya merek, produk akan lebih mudah dikenal dan lebih mudah dalam pemasarannya karena konsumen cenderung melakukan pembelian suatu produk karena mereknya.

Di Indonesia yang merupakan negara mayoritas muslim untuk menarik konsumen, produsen menggunakan strategi islamic branding. Dengan menggunakan identitas Islam ini menjadi ciri khas bagi produk tertentu. Karena merek memiliki peran penting untuk sebuah produk barang maupun jasa terutama untuk saat ini dimana masyarakat kurang memperhatikan kehalalan suatu produk. Dalam ajaran agama Islam, kehalalan suatu produk perlu dipertimbangkan karena sebelum mengkonsumsi suatu produk hendaknya produk tersebut terjamin kehalalannya.

Pada saat ini, industri kosmetik banyak dilirik oleh perusahaan karena dianggap memiliki pontensi yang besar. Ada beberapa produk yang mengusung islamic branding di bidang kecantikan atau kosmetik, salah satunya perusahaan PT Paragon Technology and Inovation dengan salah satu produknya bernama Wardah. Produk kosmetik Wardah ini bisa disebut pelopor kosmetik halal di Indonesia yang sudah terjamin kehalalan dan kelayakannya. Wardah merupakan salah satu kosmetik halal yang terkenal di Indonesia, kemunculannya membantu wanita di Indonesia untuk mendapatkan produk yang aman dan halal.

Perusahaan kosmetik harus memasukkan informasi tentang produknya. Misalnya bahan yang digunakan, bahan campuran bahan, tanggal kadaluwarsa produk, cara penggunaan dan uraian keamanan produk. Untuk lebih meningkatkan kepercayaan konsumen dan memastikan penggunaan produk yang aman, kosmetik akan diperiksa terlebih dahulu oleh Badan Pengawas Obat dan Kosmetik (BPOM).

Banyak faktor yang dapat meningkatkan minat beli konsumen salah satunya iklan atau promosi. Hal ini sangat berpengaruh besar karena konsumen akan melihat langsung 


\section{Vol 4 No 1 (2021) 111-125 P-ISSN 2620-295 E-ISSN 2747-0490 DOI: 1047467/elmal.v4i2.539}

hasil dari produk yang dijual. Karena biasanya iklan dibuat semenarik mungkin untuk memikat konsumen dan bersaing dengan produk lainnya. Kosmetik Wardah sendiri, menggunakan celebrity endorser untuk membantu pemasaran produknya. Karena hal ini, pada tahun 2011 produk wardah mendadak menjadi lebih populer dibandingkan dengan merek lainnya. Para produsen biasanya melibatkan seseorang atau lebih untuk memproduksi iklan walaupun dengan biaya yang tidak sedikit. Biasanya orang-orang yang terlibat dalam endorser ini memiliki pengaruh terhadap konsumen, seperti selebriti atau influencer. Menurut hasil penelitian Ardelia (2019: 123), penggunaan celebrity endorser pada iklan yang digunakan oleh para produsen kosmetik ternyata tidak selalu berhasil dan efektif dalam mempengaruhi para konsumen untuk melakukan pembelian.

Konsumen yang tertarik dengan suatu produk terutama kosmetik dan makanan, biasanya konsumen akan menggali informasi lebih lagi tentang merek dan bahan yang ada pada produk tersebut. Hal yang utama akan dicari tahu adalah halal tidaknya produk tersebut, terutama untuk konsumen yang beragama Islam. Pengetahuan konsumen tentang produk dengan standar halal ini masih rendah. Pada awal kemunculan produk Wardah sebagai trend hijrah pada produk islami ini pun masih sangat asing ditelinga konsumen. Pengetahuan tentang suatu produk halal nantinya menjadi sangat berpengaruh dalam pengambilan keputusan pembelian. Terutama dikalangan mahasiswi yang baru akan mencoba produk kosmetik baru karena mereka akan mecari produk yang aman dan memiliki harga standar untuk semua kalangan. Hal ini menjadi alasan mengapa peneliti menjadikan produk Wardah sebagai study penelitian yaitu dikarenakan Wardah dapat berkembang ditengah persaingan di industri kosmetik yang sedang banyak digandrungi. Selain itu, Wardah sendiri sudah menjadi pelopor produk kosmetik halal di Indonesia yang pasti aman dan layak digunakan. Produk Wardah sudah mendapatkan seertifikasi halal dari Lembaga Pengkajian Pangan, Obat, dan Makanan Majelis Ulama Indonesia (LPPOM MUI).

Berdasarkan hal tersebut peneliti tertarik untuk melakukan penelitian untuk mengetahui apakah konsumen produk kosmetik Wardah terutama dikalangan mahasiswi mengambil keputusan pembelian karena adanya pengaruh dari islamic branding, celebrity endorser dan pengetahuan produk atau karena adanya pengaruh dari faktor-faktor lain.

Berdasarkan latar belakang di atas, maka penelit tertarik untuk melakukan penelitian dengan judul: Islamic Branding, Celebrity Endorser dan Pengetahuan Produk Terhadap Keputusan Pembelian Konsumen Kosmetik Wardah (Studi Kasus Mahasiswi Fakultas Agama Islam Universitas Ibn Khaldun).

\section{LANDASAN TEORI}

\section{Islamic Branding}

Sebuah produk dapat menarik konsumen jika mempunyai merk (brand). Branding memiliki tempat dibenak konsumen, bukan di dunia nyata (Nasrullah, 


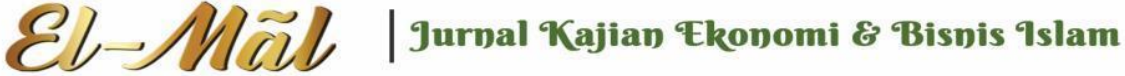

\section{Vol 4 No 1 (2021) 111-125 P-ISSN 2620-295 E-ISSN 2747-0490 DOI: $1047467 /$ elmal.v4i2.539}

2015: 81). Menurut Nasrullah, 2015:82) Islamic Branding dapat dimaknai sebagai penggunaan nama-nama yang berkaitan dengan Islam atau menunjukkan identitas halal untuk sebuah produk. Sebagai contoh: hotel syariah, rumah sakit Islam, Wardah, $\mathrm{KFC}$, dan lain-lain. Islamic branding adalah merek produk memiliki nilai positif pada kepercayaan konsumen dalam membeli dan mengkonsumsi makanan berlabel halal (Faizah, Masreviastuti: 2018: 326)

Menurut Baker dalam Nasrullah (2015: 82) Islamic branding diklasifikasikan dalam tiga bentuk:

a. Islamic brand by compliance

Islamic brand harus menunjukkan dan memiliki daya tarik dengan cara patuh dan taat kepada syariat Islam kepada konsumen. Brand yang masuk dalam kategori ini adalah produknya halal, produk yang diproduksi oleh negara Islam, dan ditujukan untuk konsumen muslim.

b. Islamic brand by origin

Penggunaan brand tanpa harus menunjukkan kehalalan produknya karena produk tersebut berasal dari negara asal yang sudah dikenal sebagai negara Islam.

c. Islamic brand by customer

Branding ini berasal dari negara nonmuslim tetapi produknya dapat digunakan oleh muslim. Brand ini biasanya menyertakan label halal pada produknya agar dapat menarik konsumen muslim.

Di Indonesia sertifikasi halal dikeluarkan resmi oleh MUI. Adapun Lembaga Pengkajian Pangan, Obat-obatan dan Kosmetika Majelis Ulama Indonesia (LPPOM MUI). LPPOM ini bertugas untuk melakukan pemeriksaan dan pengkajian ilmiah pada produk-produk makanan, minuman, obat, dan kosmetika. Sedangkan penetapan halal dan fatwa merupakan wewenang dan tugas Komisi Fatwa MUI. Untuk standar produk kosmetika yang halal sudah ada Fatwa MUI Nomor 26 Tahun 2013 tentang Standar Kehalalan Produk Kosmetika dan Penggunaannya. Di tahun 1999, PT Pusaka Tradisi Ibu melalui pabriknya telah mendapatkan sertifikasi halal dari LPPOM MUI, dengan brand kosmetik Wardah sebagai pionir brand halal di Indonesia. Wardah pernah mendapatkan "Halal Top Brand 2018” pada ajak Halal Award 2018 yang diberikan khusus oleh LPPOM MUI untuk kategori shampoo dan perawatan rambut.

\section{Celebrity Endorser}

Celebrity Endorser adalah alat pendukung yang digunakan untuk tujuan pemasaran produk. Celebrity Endorser juga dapat disebut sebagai simbol atau karakter tertentu untuk menyampaikan informasi dan/atau menampilkan informasi dan menunjukkannya untuk mempromosikan produk yang terlibat (Sari, dkk, 2019: 8176). Celebrity Endorser bisa disebut juga sebagai simbol atau karakter tertentu untuk menyampaikan sebuah pesan dan atau informasi serta memperagakan dalam rangka mempromosikan produk yang dimaksud.

\section{$114 \mid$ Volume 4 Nomor 12021}




\section{Vol 4 No 1 (2021) 111-125 P-ISSN 2620-295 E-ISSN 2747-0490 DOI: 1047467/elmal.v4i2.539}

Menurut Shimp (2003:470) dalam penelitian Cholifah, dkk (2016:172) ada lima indikator yang dijelaskan dengan akronim TEARS. TEARS ini terdiri dari:

a. Truthworthiness (dapat dipercaya) yaitu mengacu pada kejujuran, integritas dan kepercayaan diri dari seorang sumber pesan.

b. Expertise (keahlian) yaitu mengacu pada pengetahuan, pengalaman atau keahlian yang dimiliki oleh seorang endorser yang dihubungkan dengan merek yang didukung seorang endorser yang diterima sebagai seorang yang ahli pada merek yang didukungnya akan lebih persuasif dalam menarik audience daripada seorang endorser yang tidak diterima sebagai seorang yang ahli.

c. Attractiveness (daya tarik fisik) yaitu mengacu pada diri yang dianggap sebagai hal yang menarik untuk dilihat dalam kaitannya dengan konsep kelompok tertentu dengan daya tarik fisik.

d. Respect (kualitas dihargai) yaitu kualitas yang dihargai atau digemari sebagai akibat dari kualitas pencapaian personal.

e. Similarity (kesamaan dengan audience yang dituju) yaitu mengacu pada kesamaan antara endorser dan audience dalam hal umur, jenis kelamin, etnis, status sosial, dan sebagainya.

\section{Pengetahuan Produk}

Menurut Shirin dan Hanzaee (2011) dalam penelitian Irvanto dan Sujana (2020: 109) pengetahuan produk adalha pengetahuan yang didasarkan pada memori atau pengetahuan yang dimiliki oleh konsumen. Pengetahuan produk dalam bahasa Indonesia diartikan sebagai pengetahuan yang dimiliki oleh konsumen mengenai produk atau jasa yang akan atau sudah dikonsumsi. Pengetahuan produk akan membangun kepercayaan konsumen terhadap produk melalui pengetahuannya tentang produk konsumen akan mengetahui dan percaya bahwa produk yang mereka konsumsi berguna untuk memenuhi permintaan sehingga konsumen yang memahami produk dapat mengambil keputusan pembelian yang berulang.

Menurut Peter dan Olsom (2013) dalam penelitian Juniarto dan Hasanah (2020: 165) membagi tiga jenis pengetahuan produk antara lain:

a. Pengetahuan tentang karakteristik produk

Atribut suatu produk dibagi menjadi atribut fisik (menggunakan ciri-ciri fisik dari suatu produk) dan atribut abstrak (menggambarkan karakteristik subjektif dari suatu produk berdasarkan persepsi konsumen).

b. Pengetahuan tentang kepuasan manfaat produk

Ada dua jenis manfaat yang akan dirasakan konsumen setelah mengkonsumsi suatu produk yaitu manfaat fungsional dan manfaat psikososial. Manfaat fungsional adalah manfaat yang dirasakan konsumen secara psikologis. Sedangkan manfaat psikososial adalah aspek dari psikologis seperti perasaan, emosi, dan suasana hati).

c. Pengetahuan tentang kepuasan yang diberikan kepada konsumen 


\section{Jurnal Kajian Ekonomi \& Bisnis Islam}

\section{Vol 4 No 1 (2021) 111-125 P-ISSN 2620-295 E-ISSN 2747-0490 DOI: 1047467/elmal.v4i2.539}

Kepuasan konsumen setelah menggunakan atau mengkonsumsi suatu produk ini akan mempengaruhi keputusan pembelian.

\section{Keputusan Pembelian}

Menurut (Putra dkk., 2017: 126) keputusan pembelian adalah proses penentuan pilihan konsumen dari berbagai alternatif pilihan yang ada terhadap produk yang paling sesuai dengan kebutuhan yang diinginkan. Keputusan pembelian merupakan tindakan pelanggan yang digunakan pelanggan untuk membeli suatu produk (Sari dkk., 2019: 8176).

Menurut Kotler (2002) dalam penelitian Sari dkk., (2019: 8176) keputusan pembelian adalah yang dilakukan dari pelanggan untuk ingin membeli atau tidak terhadap suatu produk. Berdasarkan pengertian di atas dapat disimpulkan bahwa keputusan pembelian adalah keinginan konsumen untuk membeli suatu produk dengan melalui beberapa proses sebelum akhirnya memutuskan untuk membeli produk tersebut.

Menurut Kotler (2009) dalam penelitian Supangkat, Supriyatin (2017: 6) ada beberapa proses dalam pengambilan keputusan pembelian, yaitu pengenalan masalah, pencarian informasi, evaluasi alternative, keputusan pembelian, dan perilaku pasca pembelian.

a. Pengenalan masalah adalah proses dimana pembeli menjadi sadar akan masalah atau kebutuhan. Konsumen akan mencari tahu apa yang sedang dibutuhkan sedangkan pemasar harus mencari informasi tentang keadaan seperti apa yang akan memicu kebutuhan konsumen.

b. Pencarian informasi adalah konsumen yang tertarik untuk memenuhi kebutuhannya akan tergerak untuk mencari lebih banyak informasi mengenai apa yang dibutuhkan. Sumber informasi dapat berasal dari sumber pribadi, sumber komersial, sumber publik, dan sumber eksperimental.

c. Evaluasi alternatif adalah proses pengambilan keputusan dari informasi yang didapatkan oleh konsumen dengan mengevalusi merek-merek produk yang akan dibeli dalam beberapa pilihan.

d. Keputusan pembelian, ada dua faktor yang dapat mempengaruhi keputusan pembelian. Faktor pertama adalah pendapat orang lain terhadap suatu produk sedangkan faktor kedua adalah faktor dari situasi yang tidak diharapkan.

e. Perilaku pascapembelian adalah keadaan dimana konsumen akan mengambil tindakan dari kepuasan atau ketidakpuasan setelah membeli produk tersebut. Jika konsumen puas, mungkin saja akan membeli produk itu kembali.

\section{METODE PENELITIAN}

Penelitian ini dilakukan pada tanggal 5 Agustus 2021 hingga 8 Agustus 2021. Adapun tempat penelitian yang akan dilakukan di Fakultas Agama Islam Universitas Ibn Khaldun Bogor. Penelitian ini diperoleh dari data primer yang dipeoleh melalui penyebaran kuesioner kapada mahasiswi Fakultas Agama Islam Universitas Ibn Khaldun Bogor. 


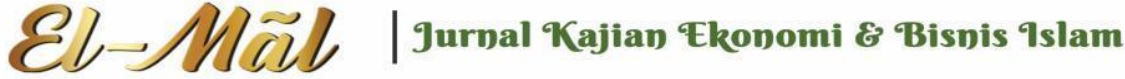

\section{Vol 4 No 1 (2021) 111-125 P-ISSN 2620-295 E-ISSN 2747-0490 DOI: $1047467 /$ elmal.v4i2.539}

Ukuran sampel pada penelitian ini sebanyak 88 sampel. Teknik pengambilan sampel yang digunakan adalah purposive sampling yaitu cara pengambilan sampel dengan menetapkan ciri atau kriteria yang sesuai dengan tujuan. Responden dari penelitian ini memiliki kriteria yaitu mahasiswi yang pernah menggunakan kosmetik Wardah. Variabel bebas (independent variable) yang digunakan dalam penelitian ini adalah Islamic branding (X1), Celebrity endorser (X2), dan Pengetahuan produk (X3). Variabel terikat (dependent variable) yang digunakan dalam penelitian ini adalah keputusan pembelian (Y). Pengujian validitas ini dilakukan untuk menguji apakah kuesioner dan responden cocok untuk digunakan dalam penelitian ini. Uji reliabilitas dalam PLS dapat menggunakan metode composite reliability dan cronbach's alpha. Metode analisis data yang digunakan adalah partial least square (PLS).

\section{HASIL PENELITIAN}

Pada penelitian ini data diperoleh dengan menyebarkan kuesioner kepada responden yang merupakan mahasiswi Fakultas Agama Islam Universitas Ibn Khaldun Bogor dengan data responden yang terkumpul sebanyak 88 responden. Hasil data dari kuesioner seluruhnya akan diolah menjadi data yang dapat digunakan untuk melanjutkan penelitian ini. Pengujian data menggunakan teknik analisis data Partial Least Square (PLS) dengan program SmartPLS 3.0. Berikut kriteria responden yang berpartisipasi dalam penelitian ini.

\begin{tabular}{|c|c|c|c|}
\hline No & Usia & Responden & Persentase \\
\hline 1. & 18 Tahun & 4 & $4 \%$ \\
\hline 2. & 19 Tahun & 8 & $9 \%$ \\
\hline 3. & 20 Tahun & 4 & $5 \%$ \\
\hline 4. & 21 Tahun & 27 & $31 \%$ \\
\hline 5. & 22 Tahun & 45 & $51 \%$ \\
\hline & Jumlah & 88 & $100 \%$ \\
\hline
\end{tabular}

Berdasarkan data di atas usia 22 tahun lebih banyak menggunakan kosmetik Wardah. hal ini menunjukan bahwa pada usia 22 tahun wanita lebih paham tentang pentingnya menggunakan kosmetik.

\section{Evaluation Measurment (Outer Model)}

a. Uji Validitas

Uji validitas dalam penelitian ini diolah menggunakan SmartPls 3.0. Untuk uji valditas konvergen ini dilihat dari skor AVE (average variance extracted) dengan nilai AVE harus < 0,5. Sebelum menguji nilai AVE, harus dilakukan terlebih dahulu melihat nilai loading factor atau outer loading. Berikut ini hasil skor loading factor atau outer loading setiap indikator terhadap konstruknya:

Gambar 1. Hasil Pengukuran Loading Factor/Outer Loading 1 


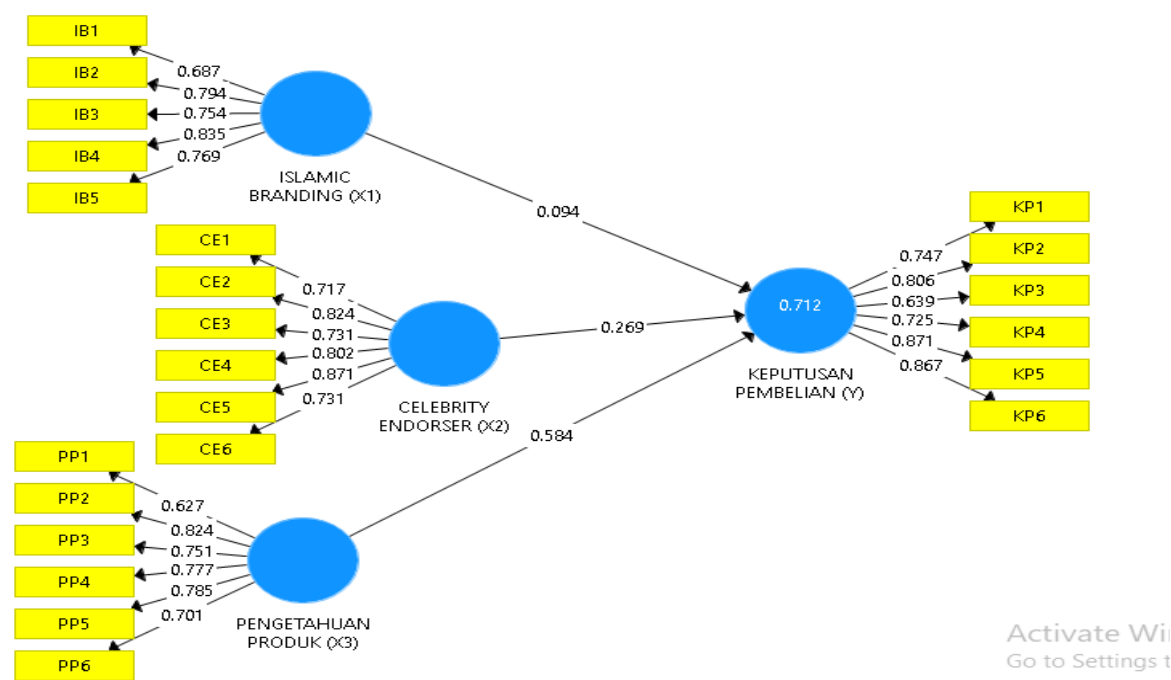

Pada gambar 1 menjelaskan bahwa ada beberapa nilai loading factor yang masih di bawah 0,70 sehingga indikator yang memiliki niai di bawah 0,70 menunjukan bahwa indikator tersebut tidak valid. Untuk mengukur validitas konvergen dalam uji validitas, nilai loading factor harus di atas 0,70. Maka dari itu, untuk indikator yang memiliki nilai di bawah 0,70 harus dikeluarkan atau dihapus dan diperhitungkan ulang.

Gambar 2. Hasil Loading Factor/Outer Loading 2

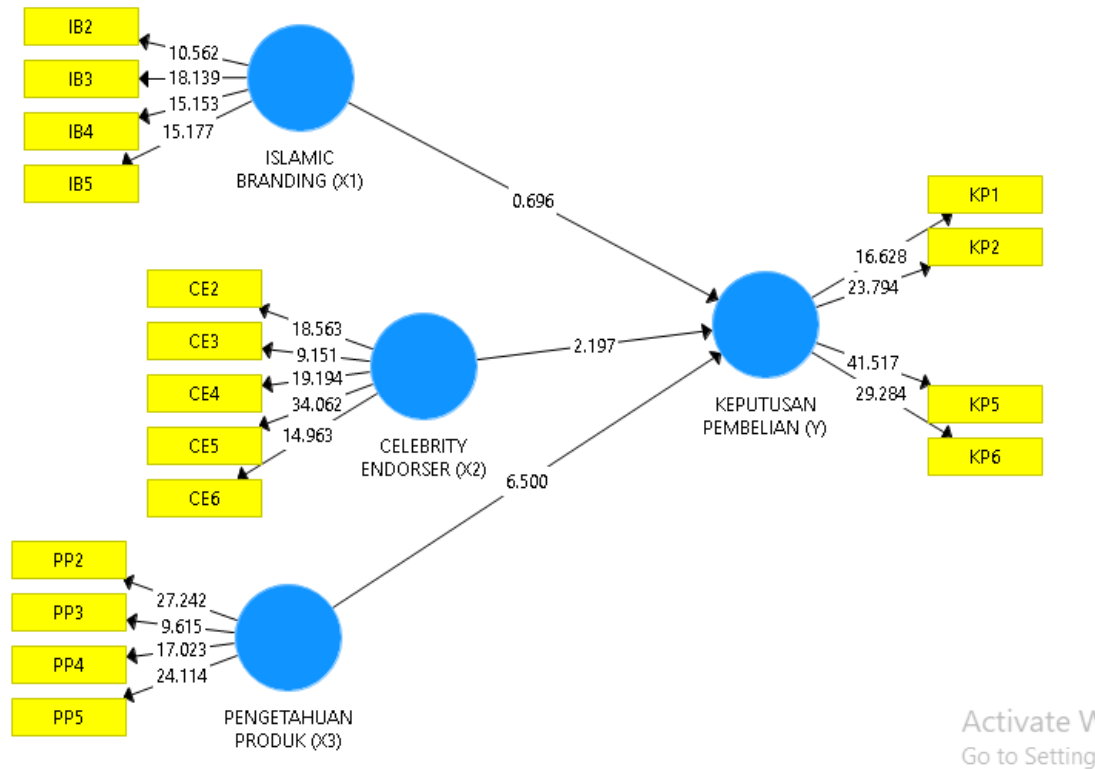

Pada gambar 2. di atas merupakan nilai loading factor setelah beberepa indikator yang tidak valid atau memiliki nilah di bawah 0,70 dikeluarkan atau 


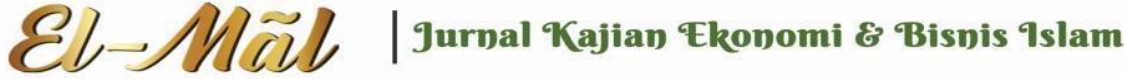

\section{Vol 4 No 1 (2021) 111-125 P-ISSN 2620-295 E-ISSN 2747-0490 DOI: $1047467 /$ elmal.v4i2.539}

dihapus. Setelah indikator IB1, CE1, PP1, PP6, KP3, dan KP4 dikeluarkan atau dihapus semua indikator sudah memiliki nilai di atas 0,70 sehingga semua indikator sudah memenuhi syarat convergent validity dan semua indikator sudah dinyatakan valid untuk bisa melanjutkan penelitian. Berikut dijelaskan nilai dari loading factor atau outer loading pada tabel berikut:

Tabel 3. Nilai Loading Factor/Outer Loading

\begin{tabular}{|c|c|c|}
\hline Variabel & Indikator & $\begin{array}{l}\text { Nilai Loading } \\
\text { Factor/Outer Loading }\end{array}$ \\
\hline \multirow{4}{*}{ Islamic Branding (X1) } & IB2 & 0.765 \\
\hline & IB3 & 0.790 \\
\hline & IB4 & 0.838 \\
\hline & IB5 & 0.794 \\
\hline \multirow{5}{*}{ Celebrity Endorser (X2) } & CE2 & 0.802 \\
\hline & CE3 & 0.702 \\
\hline & CE4 & 0.833 \\
\hline & CE5 & 0.893 \\
\hline & CE6 & 0.761 \\
\hline \multirow{4}{*}{ Pengetahuan Produk (X3) } & PP2 & 0.847 \\
\hline & PP3 & 0.735 \\
\hline & PP4 & 0.825 \\
\hline & PP5 & 0.831 \\
\hline \multirow{4}{*}{ Keputusan Pembelian (Y) } & KP1 & 0.799 \\
\hline & KP2 & 0.850 \\
\hline & KP5 & 0.901 \\
\hline & KP6 & 0.868 \\
\hline
\end{tabular}

Tabel 4. AVE

\begin{tabular}{|l|c|}
\hline \multicolumn{1}{|c|}{ Variabel } & Nilai AVE \\
\hline Islamic Branding (X1) & 0.636 \\
\hline Celebrity Endorser (X2) & 0.641 \\
\hline Pengetahuan Produk (X3) & 0.657 \\
\hline Keputusan Pembelian (y) & 0.731 \\
\hline
\end{tabular}

Validitas konvergen dinilai berdasarkan factor loading dimana nilai factor loading harus di atas 0,70. Setelah mendapatkan nilai dari factor loading maka dapat dilanjutkan dalam perhitungan AVE (Average Varlance Extracted) dimana 


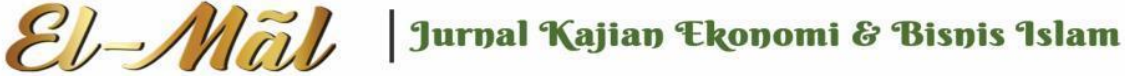

\section{Vol 4 No 1 (2021) 111-125 P-ISSN 2620-295 E-ISSN 2747-0490 DOI: $1047467 /$ elmal.v4i2.539}

nilai AVE setiap variabel di atas 0,5. Berdasarkan hasil model pengukuran pada tabel 3 dan 4 dapat dijelaskan sebaga berikut:

1) Variabel Islamic branding diukur dengan 4 indikator. Semua indikator memiliki nilai factor loading $>0,70$ dan nilai AVE $>0,5$.

2) Variabel celebrity endorser diukur dengan 5 indikator. Semua indikator memiliki nilai factor loading $>0,70$ dan nilai AVE $>0,5$.

3) Variabel pengetahuan produk diukur dengan 4 indikator. Semua indikator memiliki nilai factor loading $>0,70$ dan nilai AVE $>0,5$.

4) Variabel keputusan pembelian diukur dengan 4 indikator. Semua indikator memiliki nilai factor loading $>0,70$ dan nilai AVE $>0,5$.

Berdasarkan hasil factor loading yang sudah dijelaskan di atas maka dapat disimpulkan bahwa variabel dalam penelitian ini memiliki nilai validitas konvergen pada loading factor dan nilai AVE sudah mempunyai nilai yang baik.

\section{b. Uji Validitas Diskriminan}

Pada pengujian validitas diskriminan ini digunakan untuk mengukur apakah indikator pada suatu variabel sudah memiliki nilai yang lebih besar dari variabel lainnya. Pengujian validitas diskriminan dilakukan berdasarkan metode Fornel Lacker Criterion or HTMN dan nilai pada Cross Loading. Proses perhitungan Fornel Lacker Criterion or HTMN dilakukan dengan melihat kolerasi variabel dengan variabel itu sendiri dimana nilainya tidak boleh lebih kecil dari variabel lainnya. Berikut ini tabel nilai Fornel Lacker Criterion or HTMN:

Tabel 5. Fornel Lacker Criterion

\begin{tabular}{|c|c|c|c|c|}
\hline & $\begin{array}{c}\mathrm{X} 2 \\
\text { Celebrity } \\
\text { Endorser }\end{array}$ & $\begin{array}{c}\mathrm{X} 1 \\
\text { Islamic } \\
\text { Branding }\end{array}$ & $\begin{array}{c}\mathrm{Y} \\
\text { Keputusan } \\
\text { Pembelian }\end{array}$ & $\begin{array}{c}\mathrm{X} 3 \\
\text { Pengetahuan } \\
\text { Produk }\end{array}$ \\
\hline X2 CE & 0.801 & & & \\
\hline X1 IB & 0.575 & 0.797 & & \\
\hline Y KP & 0.601 & 0.613 & 0.855 & \\
\hline X3 PP & 0.595 & 0.703 & 0.783 & 0.811 \\
\hline
\end{tabular}

Selain dengan menggunakan Fornel Lacker Criterion, mengukur discriminant validity juga dapat diketahui berdasarkan nilai cross loading dengan syarat nilai yang dimiliki varibel harus lebih besar dari nilai variabel lainnya. Berikut ini tabel nilai validitas diskriminan dengan cross loading:

Tabel 6. Nilai Cross Loading

\begin{tabular}{|c|c|c|c|c|}
\hline & $\begin{array}{c}\text { Islamic } \\
\text { Branding } \\
(\mathrm{X} 1)\end{array}$ & $\begin{array}{c}\text { Celebrity } \\
\text { Endorser } \\
(\mathrm{X} 2)\end{array}$ & $\begin{array}{c}\text { Pengetahuan } \\
\text { Produk } \\
(\mathrm{X} 3)\end{array}$ & $\begin{array}{c}\text { Keputusan } \\
\text { Pembelian } \\
(\mathrm{Y})\end{array}$ \\
\hline IB2 & 0.765 & 0.361 & 0.533 & 0.487 \\
\hline IB3 & 0.79 & 0.472 & 0.637 & 0.546 \\
\hline
\end{tabular}




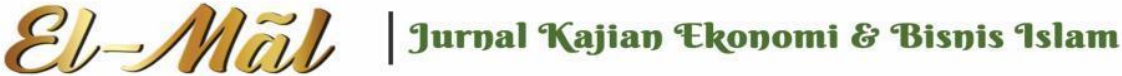

Vol 4 No 1 (2021) 111-125 P-ISSN 2620-295 E-ISSN 2747-0490 DOI: $1047467 /$ elmal.v4i2.539

\begin{tabular}{|c|c|c|c|c|} 
IB4 & 0.838 & 0.499 & 0.566 & 0.448 \\
\hline IB5 & 0.794 & 0.501 & 0.488 & 0.458 \\
\hline CE2 & 0.512 & 0.802 & 0.474 & 0.537 \\
\hline CE3 & 0.159 & 0.702 & 0.206 & 0.249 \\
\hline CE4 & 0.474 & 0.833 & 0.442 & 0.417 \\
\hline CE5 & 0.478 & 0.893 & 0.519 & 0.52 \\
\hline CE6 & 0.525 & 0.761 & 0.601 & 0.559 \\
\hline PP2 & 0.572 & 0.483 & 0.847 & 0.66 \\
\hline PP3 & 0.423 & 0.351 & 0.735 & 0.527 \\
\hline PP4 & 0.511 & 0.45 & 0.825 & 0.614 \\
\hline PP5 & 0.733 & 0.611 & 0.831 & 0.717 \\
\hline KP1 & 0.39 & 0.442 & 0.586 & 0.799 \\
\hline KP2 & 0.496 & 0.472 & 0.702 & 0.85 \\
\hline KP5 & 0.617 & 0.526 & 0.713 & 0.901 \\
\hline KP6 & 0.573 & 0.608 & 0.671 & 0.868 \\
\hline
\end{tabular}

Tabel 6 menjunjukan bahwa hasil nilai cross loading seluruh indikator pada setiap variabel memiliki nilai lebih besar dari variabel lainnya. Maka dari data tersebut dinyatakan bahwa sudah valid karena nilai kolerasi antar indikator konstruknya lebih besar dibandingkan nilai kolerasi dengan konstruk lainnya.

c. Uji Reliabilitas

Uji realiabilitas diukur dengan metode Composite Reliability dan Cronbach's Alpha. Composite reliability adalah nilai yang digunakan untuk mengukur konsistensi indikator pada nilai variabel. Suatu variabel dapat dinyatakan reliabel jika memilii nilai composite reliability $>0,7$ dan nilai cronbach's alpha $>0,7$. Berikut ini hasil pengujian composite reliability dan cronbach's alpha:

Tabel 7. Composite Reliability dan Cronbach's Alpha

\begin{tabular}{|c|c|c|}
\hline & $\begin{array}{c}\text { Composite } \\
\text { Reliability }\end{array}$ & Cronbach's Alpha \\
\hline Islamic Branding (X1) & 0.875 & 0.809 \\
\hline Celebrity Endorser (X2) & 0.899 & 0.862 \\
\hline Pengetahuan Produk (X3) & 0.884 & 0.826 \\
\hline Keputusan Pembelian (Y) & 0.916 & 0.877 \\
\hline
\end{tabular}

Dari data pada tabel 7 menunjukan bahwa nilai composite reliability dan nilai cronbach's alpha sudah memenuhi syarat uji reliabilitas dimana semua variabel memiliki nilai $>0,7$ sehingga dapat disimpulkan bahwa nilai reliabilitas pada semua variabel memilki nilai yang baik.

\section{Evaluation of Structural Model (Inner Model)}




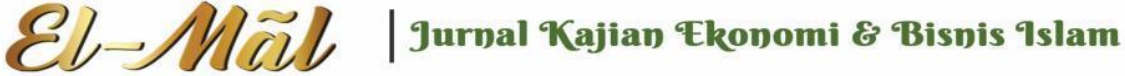

\section{Vol 4 No 1 (2021) 111-125 P-ISSN 2620-295 E-ISSN 2747-0490 DOI: $1047467 /$ elmal.v4i2.539}

Inner model adalah model structural yang diukur dengan menggunakan $R$-square untuk variabel dependen dan nilai koefisien jalur untuk variabel independen yang kemudian disignifikasi berdasarkan nilai $t$-statistic.

Tabel 8. Nilai $R$-square

\begin{tabular}{|l|r|}
\hline & R-Square \\
\hline Keputusan Pembelian (Y) & 0.644 \\
\hline
\end{tabular}

Dari hasil nilai $R$-Square, selanjutnya dapat dihitung menggunakan rumus:

Hasil dari perh $\begin{array}{ll}R \text {-square } & \text { x } 100 \\ 0,644 & \mathrm{x} 100=64 \%\end{array}$ kan dapat diartikan bahwa variabel dependen atau variabel keputusan pembelian dapat dipengaruhi oleh variabel independen atau variabel Islamic branding, celebrity endorser, dan pengetahuan produk sebesar 0,644 atau 64\%. Sedangkan sisa dari persentase sebanyak 34\% itu dipengeruhi oleh varibel lain yang tidak diujikan. Setelah perhitungan nilai $R$-square, selanjutnya melakukan perhitungan koefisien jalur atau uji path coefficient.

Tabel 9. Nilai Path Coefficient (Mean, STDEV, t-statistic)

\begin{tabular}{|c|r|r|r|r|}
\hline & \multicolumn{1}{|c|}{$\begin{array}{c}\text { Path } \\
\text { Coefficients }\end{array}$} & Sample Mean & STDEV & t-statistic \\
\hline $\begin{array}{c}\text { Islamic Branding (X1) -> } \\
\text { Keputusan pembelian (Y) }\end{array}$ & 0.064 & 0.073 & 0.092 & 0.696 \\
\hline $\begin{array}{c}\text { Celebrity Endorser (X2) -> } \\
\text { Keputusan pembelian (Y) }\end{array}$ & 0.194 & 0.203 & 0.088 & 2.197 \\
\hline $\begin{array}{c}\text { Pengetahuan Produk (X3) - } \\
>\text { Keputusan pembelian (Y) }\end{array}$ & 0.623 & 0.612 & 0.096 & 6.500 \\
\hline
\end{tabular}

Dari hasil tabel 9 menunjukan bahwa semua nilai path coefficient dari veriabel independen kepada variabbel dependen dengan angka yang positif. Semakin besar angka pada path coefficient pada satu variabel independen maka semakin kuat pula pengaruh antar variabel independen terhadap variabel dependen.

\section{Hasil Uji Hepotesis}

Uji hipotesis dapat dilihat dari nilai $t$-statistic (bootstrapping) dan nilai $P$ Values antara variabel independen ke variabel dependen. Hipotesis dalam penelitian ini dapat diterima jika nilai $t$-statistic $>1,96$ dan nilai tingkat signifikansi $P$-values sebesar $<0,05$. 


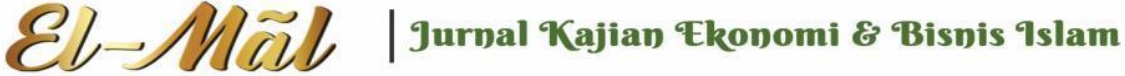

\section{Vol 4 No 1 (2021) 111-125 P-ISSN 2620-295 E-ISSN 2747-0490 DOI: $1047467 /$ elmal.v4i2.539}

Tabel 10. Nilai t-statistic dan P-Values

\begin{tabular}{|c|c|c|c|}
\hline & t-statistic & P-Values & Hasil \\
\hline $\begin{array}{c}\text { Islamic Branding (X1) -> } \\
\text { Keputusan pembelian (Y) }\end{array}$ & 0.696 & 0.487 & DITOLAK \\
\hline $\begin{array}{c}\text { Celebrity Endorser (X2) -> } \\
\text { Keputusan pembelian (Y) }\end{array}$ & 2.197 & 0.028 & DITERIMA \\
\hline $\begin{array}{c}\text { Pengetahuan Produk (X3) -> } \\
\text { Keputusan pembelian (Y) }\end{array}$ & 6.500 & 0.000 & DITERIMA \\
\hline
\end{tabular}

Berdasarkan hasil nilai tabel 10, dapat diketahui bahwa variabel islamic branding tidak diterima karena nilai $t$-statistic $<1,96$ tetapi berpengaruh positif sesuai hasil path coeffisien pada tabel 9.4 sedangkan variabel celebrity endorser dan keputusan pembelian hasilnya dapat diterima sehingga dinyatakan memiliki pengaruh yang signifikan.

Setelah melakukan perhitung $t$-statistic dan $P$-Values, maka dapat dilanjutkan dengan melakukan uji predictive relevan dimana pada uji ini nilai yang digunakan untuk menentukan sebarapa baik observasi yang dilakukan. Jika nilai yang didapat di atas 0 maka dinyatakan memiliki nilai observasi yang bagus.

Tabel 11. Nilai Predictive Relevan

\begin{tabular}{|c|c|c|r|}
\hline & SSO & SSE & $Q^{2}(=1-\mathrm{SSE} / \mathrm{SSO})$ \\
\hline Islamic Branding (X1) & 352.000 & 352.000 & \\
\hline Celebrity Endorser (X2) & 440.000 & 440.000 & \\
\hline Pengetahuan Produk (X3) & 352.000 & 352.000 & \\
\hline Keputusan Pembelian (Y) & 352.000 & 191.239 & 0.457 \\
\hline
\end{tabular}

\section{PEMBAHASAN}

Berdasarkan hasil penelitian tentang "Pengaruh Islamic Branding, Celebrity Endorser dan Pengetahuan Produk Terhadap Keputusan Pembelian Konsumen Produk Kosmetik Wardah" penelitian ini dilakukan dengan mengambil sampel mahasiswi di Fakultas Agama Islam Universitas Ibn Khaldun Bogor yang pernah menggunakan kosmetik Wardah. Berdasarkan hasil perhitungan dengan menggunakan smartPLS 3.0 menunjukan nilai $t$-statistic sebesar 0,096 dimana nilai ini lebih kecil dari $t$-statistic $>1.96$ dan nilai $P$-values sebesar 0,487 dimana hasil ini lebih besar dari nilai signifikan $<0,05$. Besarnya pengaruh variabel islamic branding terhadap variabel keputusan pembelian dalam nilai path coefficients sebesar 0,064 bernilai positif. Berdasarkan hasil tersebut maka Islamic branding berpengaruh positif tetapi tidak signifikan terhadap keputusan pembelian kosmetik Wardah.

Hasil perhitungan variabel celebrity endorser menunjukan nilai $t$-statistic sebesar 2,197 dimana nilai ini lebih besar dari t-statistic $>1.96$ dan nilai P-values sebesar 0,028 dimana hasil ini lebih kecil dari nilai signifikan $<0,05$. Besarnya pengaruh variabel 


\section{| Jurnal Kajian Ekonomi \& Bisnis Islam}

\section{Vol 4 No 1 (2021) 111-125 P-ISSN 2620-295 E-ISSN 2747-0490 DOI: $1047467 /$ elmal.v4i2.539}

celebrity endorser terhadap variabel keputusan pembelian dalam nilai path coefficients sebesar 0,194 bernilai positif. Berdasarkan hasil tersebut maka islamic branding berpengaruh positif dan signifikan terhadap keputusan pembelian kosmetik Wardah dan untuk perhitungan variabel pengetahuan produk menunjukan nilai $t$-statistic sebesar 6,500 dimana nilai ini lebih besar dari $t$-statistic $>1.96$ dan nilai P-values sebesar 0,000 dimana hasil ini lebih kecil dari nilai signifikan $<0,05$. Besarnya pengaruh variabel pengetahuan produk terhadap variabel keputusan pembelian dalam nilai path coefficients sebesar 0,623 bernilai positif. Berdasarkan hasil tersebut maka pengetahuan produk berpengaruh positif dan signifikan terhadap keputusan pembelian kosmetik Wardah.

\section{KESIMPULAN}

Berdasarkan hasil penelitian dan pembahasan maka dapat diambil kesimpulan sebagai berikut:

1. Variabel Islamic branding berpengaruh positif tapi tidak signifikan terhadap keputusan pembelian. Hal ini dibuktikan dari hasil t-statistic Islamic branding terhadap keputusan pembelian sebesar 0.696 sehingga hipotesis ditolak karena nilai t-statistic $>1,96$. Sedangkan nilai path coefficient variabel Islamic branding terhadap keputusan pembelian sebesar 0.064 yang berarti memiliki nilai positif.

2. Variabel celebrity endorser berpengaruh positif dan signifikan terhadap keputusan pembelian. Hal ini dibuktikan dari hasil t-statistic celebrity endorser terhadap keputusan pembelian sebesar 2.197 sehingga hipotesis diterma karena nilai $t$ statistic $>1,96$. Sedangkan nilai path coefficient variabel celebrity endorser terhadap keputusan pembelian sebesar 0.194 yang berarti memiliki nilai positif.

3. Variabel pengetahuan produk berpengaruh positif dan signifikan terhadap keputusan pembelian. Hal ini dibuktikan dari hasil $t$-statistic pengetahuan produk terhadap keputusan pembelian sebesar 6.500 sehingga hipotesis diterma karena nilai t-statistic $>1,96$. Sedangkan nilai path coefficient variabel pengetahuan produk terhadap keputusan pembelian sebesar 0.623 yang berarti memiliki nilai positif.

Berdasarkan hasil nilai $R$-square menunjukan bahwa variabel dependen atau variabel keputusan pembelian dapat dipengaruhi oleh variabel independen atau variabel Islamic branding, celebrity endorser, dan pengetahuan produk sebesar 0,644 atau 64\%. Sedangkan sisa dari persentase sebanyak $34 \%$ itu dipengeruhi oleh varibel lain yang tidak diujikan.

\section{DAFTAR PUSTAKA}

Ardelia, A. S. (2019). Pengaruh Islamic Branding dan Celebrity Endorser Terhadap Keputusan Pembelian Konsumen Kosmetik Halal Pada Mahasiswi Di Yogyakarta (Master's thesis, Universitas Islam Indonesia).

Cholifah, N., \& Hidayat, K. (2016). Pengaruh Celebrity Endorser 


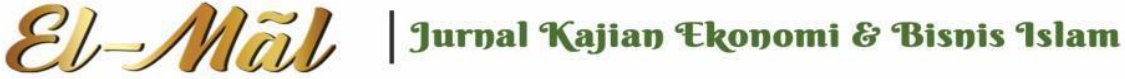

\section{Vol 4 No 1 (2021) 111-125 P-ISSN 2620-295 E-ISSN 2747-0490 DOI: $1047467 /$ elmal.v4i2.539}

Terhadap Brand Image (Survei pada Konsumen Kosmetik Wardah di Counter Wardah Kota Malang). Jurnal Administrasi Bisnis, 36(1), 170-177.

Faizah, H., \& Masreviastuti, M. (2019). Pengaruh Gaya Hidup dan Islamic Branding Terhadap Keputusan Pembelian Produk Wardah. Jurnal Aplikasi Bisnis, 4(2), 325328.

Irvanto, O., \& Sujana, S. (2020). Pengaruh Desain Produk, Pengetahuan Produk, Dan Kesadaran Merek Terhadap Minat Beli Produk Eiger. Jurnal Ilmiah Manajemen Kesatuan, 8(2), 105-126.

Juniarto, G., \& Hasanah, H. (2020). Studi tentang Minat Beli Sepeda Motor Yamaha NMax Di Kota Semarang. Serat Acitya, 1(2), 162.

Nasrullah, Muhamad. (2015). Islamic Branding, Religiusitas Dan Keputusan Konsumen Terhadap Produk. Jurnal Hukum Islam (JHI), Volume 13.

Putra, G. P., Arifin, Z., \& Sunarti, S. (2017). Pengaruh Kualitas Produk Terhadap Keputusan Pembelian dan Dampaknya Terhadap Kepuasan Konsumen (Survei Pada Mahasiswa Administrasi Bisnis Fakultas Ilmu Administrasi Angkatan 2013 dan 2014 Universitas Brawijaya Yang Melakukan Pembelian Paket Data Kampus). Jurnal Administrasi Bisnis, 48(1), 124-131.

Sari, Septi Dwi Kurnia. Dkk. (2019). Pengaruh Penggunaan Celebrity Endorser dan Promotion diMedia Sosial Instagram yang dimediasi Minat Beli Terhadap Keputusan Pembelian (Studi Pada Princess Fazion Malang). Jurnal Pengembangan Teknologi Informasi dan Ilmu Komputer. Vol.3 No.8.

Supangkat, A. H., \& Supriyatin, S. (2017). Pengaruh citra merek, kualitas produk, harga terhadap keputusan pembelian tas di intako. Jurnal Ilmu dan Riset Manajemen (JIRM), 6(9). 